\title{
State support mechanisms of small and midsize business entities
}

\author{
Vera Vorobyeva $^{1 *}$ \\ ${ }^{1}$ Smolensk institute of economics - a branch of the St. Petersburg university of technologies of \\ management and economics, Smolyaninova str.,5, Smolensk, 214031, Russia
}

\begin{abstract}
The article deals with the relevant problems of using state support mechanisms for the development of small and midsize business in Russia and the further usage of its competitive advantages at the present stage of the market economy functioning. Great attention is paid on the current condition of the development of small and midsize enterprises (the usage of state support tools based on the Conception of long-term social and economic development of Russia, the program of development in regions). In the nearest future small and midsize business is considered to be the most important stabilization factor of social and economic development of the country and its regions.
\end{abstract}

\section{Introduction}

Small and midsize business (SMB) is one of the key point of the economy at the present stage. It is the one to be given the important role in overcoming the crises consequences and further quality growing of Russian economy. Small business has potential opportunities they are allowed enterprises to be more mobile in the dynamic environment of market economy and have competitive advantages. In the process of establishing and future developing of small enterprises new workplaces are created, fair competition is formed, quick market satiety with necessary goods and services occurs. It should be emphasized that innovations are introduced more actively due to the development of small and midsize business. This sector of economy is therefore the very instrument of further development on which the state structures as well as the entrepreneurs are oriented. Small enterprises are unstable entrepreneurial structures by nature; they are more dependent on the market fluctuation and need various forms of state support. Therefore state regulation and support of entrepreneurial activity is the condition for the stable and efficient functioning of small and midsize entrepreneurial structures under the transformation of economic system in the development of its market forms and building institutional infrastructure. Russia is also building the creation of an effective governmental regulation and support system of small and midsize business. This problem is protracted by nature but it is still actual for the aims of the investigation.

«State policy in the countries with market system of management considers small enterprises not to be a smaller model or an intermediate stage in the development of a large

\footnotetext{
*Corresponding author: vero4ka111261@mail.ru
} 
firm but a special model with specific features and laws of development which demands a special approach. It is the state that determines the fortune of small business. In most developed countries the state gives the small business some kind of advantages which ultimately allows to increase the viability of small enterprises. Stabilization of small business activity in such countries is provided by law» [1].

Today the system of state regulation and support of SMB (except the legal, financial, consulting support, development SMB infrastructure support, life support, innovation activity support, support in the sphere of personal training and retraining, international cooperation in the small and midsize business sector) demands the development of efficient tools enabling to take into consideration strategically important directions of growth typical for countries with innovation-driven economies. The search of efficient mechanisms of entrepreneurial activity development goes in the following directions: finance and property related, infrastructural, informational, institutional, structural and functional connections. $[2,3]$. In Russian system of state regulation and support of SMB the tools of support of strategically important economic sectors, so called «growth points», are poorly developed. In our research these «growth points» include SMB in the business service sector in advertising, HR consulting, engineering, financial intermediation, legal services, development and realtor services, Web and Digital services. Environmentally adapted business as well as technological business should be taken as strategic points of development.

In the structure of supporting tools of the growth points subsides to profile enterprises can be considered, they can also be given for modernization, microfinancing, grants for the aspiring entrepreneurs, investment loan, investments by purchasing a share in the authorized capital and etc.

In the subjects of the Russian Federation small and midsize business is mostly concentrated in the fields of trade and services to people According to the governmental estimation of the 25-years of development entrepreneurial business economy is represented by $1 / 3$ and more of gross domestic product and by $1 / 5$ of gross regional product.

However in the list of direction of state regulation and support of small and midsize business we haven't discovered the directions of the entrepreneurial business development in the fields and directions which can confirm the pass to the mostly innovative development of the economy of an efficiency-driven country. These fields include the sector of business service, environmentally adapted business and etc.

According to the types of economies offered in the Global Competitiveness Report entrepreneurial business is defined in the three groups of countries of the world:

1 group. Factor-driven economies .

2 group. Efficiency-driven economies.

3 group. Innovation-driven economies [2].

To the group of the countries with efficiency-driven economies together with Russia Argentina, Bosnia, Brazil, China, Columbia, Croatia, Chile, Ecuador, Estonia, Guatemala, Hungary, Indonesia, Jamaica, Latvia, Lithuania, Macedonia, Malaysia, Mexico, Panama, Peru, Poland, Republic of South Africa, Rumania, Slovakia, Suriname, Thailand, Uruguay should be included. 3 group of the world economies includes Belgium, Canada, Czech Republic, Finland, France, Great Britain, Germany, Greece, Holland, Israel, Ireland, Italy, Japan Korea, Luxembourg, Norway, Portugal, Puerto Rico, Spain, Singapore, Slovenia, Sweden, Switzerland, Taiwan, Trinidad and Tobago, USA. These countries demonstrate the high activity in the sector of service for business. Sustainable competitive advantages in this case are defined by innovations.

Investigation of Russian economic activities of SMB allows to classify the problems and strategic directions of support. The following points are identified as the basic approaches of state support strategy realization of small and midsize business: 
- support on different levels: federal, regional and municipal support of SMB development;

- the practice of SMB life cycle development from its registration to the realization of well-established business activity as well as taking decision about reprofiling or activity termination;

- taking into account the concrete stages of SMB development, either it is reducing of the administrative barriers at the beginning or improving the mechanisms of state regulation and support of their activity;

- approaches connected with the providing of realization of SMB development stabilizing factors in view of the risk and uncertainty of business activity;

- legal support of SMB activity including audit expenses, the opportunity to choose special tax regimes, tax amnesty and etc.;

- infrastructural support of SMB;

- institutional support of SMB development connected with the development of state regulation and support institutions.

The following aspects are also included by S. Ivanov into the basic approaches of the state support realization strategy of SMB in industrialized countries [1]:

- improving managers skill level;

- solving the regional problems, the development of depressed regions in particular;

- developing of technological business considering the problem of access to venture financing;

- opportunities of usage of constantly developing marketing tools of SMB development (exhibitions, fairs, forums etc. ).

The above mentioned approaches were proved in Strategies for the development of small and midsize businesses for the period up to 2030 approved by Government Order of the Russian Federation № 1083 - $r$ of 2, June 2006. This order is prepared in accordance with Federal Law «About strategic planning in the Russian Federation» of 28, June 2006

The list of strategic indicators in the document includes [5].

- the growth of product turnover of SMB 2.5 times in accordance with constant prices compared with 2014 (in real terms);

- the growth of labor productivity at small and midsize business enterprises 2.5 times at the рост в 2,5 in accordance with constant prices compared with 2014 (in real terms);

- the growth of manufacturing industry share presented by SMB (without taking into account individual entrepreneurs) up to $20 \%$;

- the increase in the proportion of the employed population in the SMB sector up to $35 \%$

- double increase (from $20 \%$ to $40 \%$ ) of proportion of SMB in gross domestic product.

As it is seen from the list of strategic indicators of the development for the period including 2030 the business service is left out. The list does not also include the environmentally adapted business development.

Business services are fixed in the task groups of MSB. Two sectors are established in the document:

1. Mass sector including entrepreneurship in the sector of trade, consumer services, production and sales of agricultural goods.

2. Highly-technological sector has 3 criterias: export orientation, manufacturing industry proportion, business services and innovative enterprises.

Business services are taken into consideration as well as primary sector, building and manufacturing and consumer services sector. In Russia the proportion of entrepreneurs providing commercial, information, finance services for business is much lower than in 
countries with innovation-driven economies. The proportion presented in the structure of economic activity of business service is a business activity characteristic feature of the countries from the third group. In all world economies entrepreneurship in the sector of consumer services prevails in the structure of activities types. The distribution by types of activities in Russia and in the second and third groups of the countries are shown in table 1.

Table 1. The distribution of entrepreneurs according to the sectors of economy in Russia, in countries with efficiency-driven and innovation-driven economies 2016, \%.

\begin{tabular}{|l|l|c|c|c|c|}
\hline Types of business & $\begin{array}{l}\text { Types of } \\
\text { economies }\end{array}$ & $\begin{array}{c}\text { Primary } \\
\text { sector }\end{array}$ & $\begin{array}{c}\text { Building and } \\
\text { manufacturing }\end{array}$ & $\begin{array}{c}\text { Business } \\
\text { services }\end{array}$ & $\begin{array}{c}\text { Consumer } \\
\text { service } \\
\text { sector }\end{array}$ \\
\hline $\begin{array}{l}\text { Established } \\
\text { entrepreneurs } \\
\text { (more than } \\
\text { years) }\end{array}$ & Russia & 11 & 40 & 15 & 34 \\
\cline { 2 - 6 } & $\begin{array}{l}\text { Efficiency-driven } \\
\text { economies }\end{array}$ & 10 & 28 & 11 & 51 \\
\cline { 2 - 6 } & $\begin{array}{l}\text { Innovation-driven } \\
\text { economies }\end{array}$ & 8 & 28 & 28 & 36 \\
\hline $\begin{array}{l}\text { Early-stage } \\
\text { entrepreneurs (less } \\
\text { than 3,5 years) }\end{array}$ & Russia & 6 & 37 & 9 & 48 \\
\cline { 2 - 6 } & $\begin{array}{l}\text { Efficiency-driven } \\
\text { economies }\end{array}$ & 7 & 22 & 12 & 59 \\
\cline { 2 - 6 } & $\begin{array}{l}\text { Innovation-driven } \\
\text { economies }\end{array}$ & 4 & 22 & 27 & 47 \\
\hline
\end{tabular}

Business service in accordance with this distribution of entrepreneurs in Russia, in countries with efficiency-driven and innovation-driven economies are shown in table 2 basing on the National reports "Global entrepreneurship monitor. Russia» 2012, 2013, 2014 and 2016. It should be emphasized that the business sector will be rather presented by midsize business with higher proportion of value added than by small business. At present a considerable proportion of midsize business is represented in trade and consumer service. However the sector of entrepreneurship economy is also dynamically developed, it is presented in manufacturing industry, building, agriculture by the high proportion of value added which is also a characteristic of a business sector.

Table 2. Business service in accordance with distribution of entrepreneurs in economic sectors of Russia and countries with efficiency-driven and innovation-driven economies, (\%).

\begin{tabular}{|c|c|c|c|c|c|c|}
\hline Types of business & $\begin{array}{l}\text { Types of } \\
\text { economies }\end{array}$ & 2011 & 2012 & 2013 & 2014 & 2015 \\
\hline \multirow[t]{3}{*}{$\begin{array}{l}\text { Established } \\
\text { entrepreneurs } \\
\text { (more than } 3,5 \\
\text { years) }\end{array}$} & Russia & 8 & 80 & 6 & $\begin{array}{l}\text { In } 2015 \text { the } \\
\text { report for } \\
2014 \text { was not } \\
\text { made }\end{array}$ & 15 \\
\hline & $\begin{array}{l}\text { Efficiency-driven } \\
\text { economies }\end{array}$ & 15 & 17 & 12 & & 11 \\
\hline & $\begin{array}{l}\text { Innovation-driven } \\
\text { economies }\end{array}$ & 28 & 17 & 27 & & 28 \\
\hline \multirow{3}{*}{$\begin{array}{l}\text { Early-stage } \\
\text { entrepreneurs (less } \\
\text { than } 3,5 \text { years) }\end{array}$} & Russia & 9 & 9 & 12 & & 9 \\
\hline & $\begin{array}{l}\text { Efficiency-driven } \\
\text { economies }\end{array}$ & 13 & 19 & 13 & & 11 \\
\hline & $\begin{array}{l}\text { Innovation-driven } \\
\text { economies }\end{array}$ & 26 & 29 & 28 & & 27 \\
\hline
\end{tabular}

The strategy provides for the gradual increasing of manufacturing industry part in the output of small and midsize business entities (without individual entrepreneurs): in 2018-up to $13.5 \%$; in 2020 up to $14.4 \%$; in $203020.0 \%$ will be achieved.

The strategy is taken by the government as a basic document which is the background for the development and realization of the state programs on all levels of management. 
Planning of the above mentioned business sector, environmentally adapted manufactures is left out from the sphere of investigation in this document so in the system of support and regulation of SMB this factor can be regarded as a destabilization one in the economy of entrepreneurship and the system of the state regulation of the economy business sector .

\section{Conclusions}

It should be mentioned that the investigation has some limitation connected with the specific character of approaches taken from the methodology of the project Global Entrepreneurships Monitor, GEM. The approaches are systematically important since the entrepreneurship is considered as a process taken all stages of entrepreneurial organization development from the start-up stage of making new business to a company with its history which can be considered as a company with stable business. For our investigation it is important that such approaches allow to connect and range all factors influencing the system of SMB state regulation and support both stimulating and deterrent. Data of national economic statistic are classically used. The following specific methods of information gathering in GEM project were used:

1. The survey of adult able-bodied population with the usage of a specially made questionnaire adapted according to the country taken part in the project.

2. National expert interviews within the method of expert estimates. Entrepreneurs and experts in the field of business are taken as the experts.

Thus the efficient system of state regulation and support in small and midsize forms cannot be built independently from the strategic directions of entrepreneurship economy development.

Russia as a country with efficiency-driven economy beginning from 2011 shows the growth vector of business service provided by small and midsize business. The same vector of the development is stably demonstrated by innovation-driven economies of the countries in the world.

Methods and tools of state regulation and support of MSB should be oriented on the development of this entrepreneurship economic sector. Appropriate changes should be supported by the changes in the hierarchy of institutions of state regulation and support of $\mathrm{MSB}$, in the changes of institutional barriers of entrepreneurship economy.

\section{References}

1. S. Ivanov, Small business formation in Russia: methods and mechanisms of state regulation $(\mathrm{SPb}, 2008)$

2. URL: https://cyberleninka.ru/article/n/formirovanie-sistemy-infrastrukturnoypodderzhki-malogo-i-srednego-predprinimatelstva

3. A. Nurmukhametov, Theory and practice of state regulation and support of small and midsize business entities development, APEL 3, 83 (2014)

4. O. Verkhovskaya, National report: «Global entrepreneurship monitor. Russia, 2012», http://www.gsom.spbu.ru /files/upload/reseach/gem_full_13.pdf.

5. Government Order of the Russian Federation № 1083 - r of 2 (2006) http://docs.cntd.ru/document/420359173 